Кравець Ірина Вікторівна кандидат економічних наук, доцент, доцент кафедри економічної теорії, інтелектуальної власності та публічного управління, Поліський національний університет, Старий бульвар, 7, Житомир, 10002, e-mail: ikravets2009@ukr.net, https://orcid.org/0000-0001-5919-6560

Якобчук Валентина Павлівна кандидат економічних наук, професор, завідувач кафедри економічної теорії, інтелектуальної власності та публічного управління, Поліський національний університет, Старий бульвар, 7, Житомир, 10002, e-mail: valentyna.iakobchuk@gmail.com, https://orcid.org/0000-0003-21477994

Симоненко Леся Іванівна кандидат економічних наук, доцент, доцент кафедри економічної теорії, інтелектуальної власності та публічного управління, Поліський національний університет, Старий бульвар, 7, Житомир, 10002, e-mail: lesia.simonenko@gmail.com

\title{
КЛАСИЧНІ ТА ІННОВАЦІЙНІ ПІДХОДИ В СИСТЕМІ БЕЗПЕРЕРВНОГО ПРОФЕСІЙНОГО НАВЧАННЯ ПУБЛІЧНОГО СЛУЖБОВЦЯ
}

Анотація. В результаті дослідження було здійснено аналіз літературних джерел та нормативно-правового забезпечення, в результаті якого розкрито сутність класичних та інноваційних підходів в системі безперервного професійного навчання публічного службовця. Так, в класичних підходах до навчання державних кадрів приділяється значна увага формуванню нових знань та навичок у сфері збільшення державного доходу, функціонуванні суспільних систем на основі централізованої ієрархічної моделі державного управління без проявів політичної активності службовців. Інноваційні підходи на відміну від класичних роблять значний акцент на здобуття нових знань та навичок в сфері державного управління на засадах демократії, децентралізації та відкритості влади, електронному урядуванні. Встановлено, що розвиток системи професійного навчання публічного службовця тісно пов'язаний iз трансформацією суспільства в контексті зміни моделей публічного управління та типу соціально-економічних систем. Проаналізовано історичні та соціальнополітичні аспекти становлення сучасної системи професійного навчання публічного службовця. Визначено принципи оновленої системи професійного 
навчання публічного службовця, серед яких основними $є$ інноваційність, можливість прикладного застосування, відкритість, цілеспрямованість та географічна наближеність надання освітніх послуг до місця проживання публічного службовця. Визначено складові інституційної структури та національної мережі закладів системи професійного навчання публічних службовців. Досліджено питання якості та результати навчання студентів за спеціальністю «Публічне управління та адміністрування» на базі Поліського національного університету (ЖНАЕУ). Перспективою дослідження є подальше удосконалення системи професійного навчання публічного службовця в контексті відповідності сучасним соціально-політичним та економічним викликам $\epsilon$ посилення уваги на засвоєння публічними службовцями нових знань навичок в сфері електронного урядування, комунікаційних технологій влади та суспільства та протидії корупції.

Ключові слова: система професійного навчання публічних службовців, підвищення кваліфікації державних службовців, безперервна система навчання публічних службовців.

Kravets Iryna Viktorivna $\mathrm{PhD}$ in Economics, Associate Professor, Associate Professor of the Department of Economic Theory, Intellectual Property and Public Administration, Polissia National University, Staryy boulevard, 7, Zhytomyr, 10002, email: ikravets2009@ukr.net, https://orcid.org/0000-0001-5919-6560

Yakobchuk Valentyna Pavlivna $\mathrm{PhD}$ in Economics, Professor, Head of the Department of Economic Theory, Intellectual Property and Public Administration, Polissia National University, Staryy boulevard, 7, Zhytomyr, 10002, e-mail: valentyna.iakobchuk@gmail.com, https://orcid.org/0000-0003-2147-7994

Symonenko Lesya Ivanivna $\mathrm{PhD}$ in Economics, Associate Professor, Associate Professor of the Department of Economic Theory, Intellectual Property and Public Administration, Polissia National University, Staryy boulevard, 7, Zhytomyr, 10002, e-mail: lesia.simonenko@gmail.com

\section{CLASSICAL AND INNOVATIVE APPROACHES IN THE SYSTEM OF CONTINUOUS PROFESSIONAL TRAINING OF A PUBLIC EMPLOYEE}

Abstract. As a result of the research, an analysis of literature sources and regulatory support was carried out, as a result of which the essence of classical and innovative approaches in the system of continuous professional training of a public servant was revealed. Thus, in the classical approaches to the training of public 
personnel, considerable attention is paid to the formation of new knowledge and skills in increasing public income, the functioning of social systems based on a centralized hierarchical model of public administration without political activity of employees. Innovative approaches, in contrast to the classical ones, place a significant emphasis on acquiring new knowledge and skills in the field of public administration on the basis of democracy, decentralization and openness of power, e-government. It is established that the development of the system of professional training of public servants is closely related to the transformation of society in the context of changing models of public administration and the type of socio-economic systems. The historical and sociopolitical aspects of the formation of a modern system of professional training of public servants are analyzed. The principles of the renewed system of professional training of a civil servant are determined, among which the main ones are innovation, applicability, openness, purposefulness and geographical proximity of educational services to the place of residence of a civil servant. The components of the institutional structure and the national network of institutions of the system of professional training of public servants are determined. The issues of quality and results of students' study in the specialty "Public Administration" on the basis of Polissia National University (ZNAEU) are studied. The prospect of the study is to further improve the system of professional training of civil servants in the context of modern socio-political and economic challenges.

Keywords: system of professional training of civil servants, advanced training of civil servants, continuous system of training of civil servants.

Постановка проблеми. В умовах децентралізації державного управління постає актуальне питання забезпечення органів влади достатньою кількістю нових професійних кадрів та вдосконалення вже набутих професійних знань, умінь та навичок публічних службовців відповідно до сучасних вимог та викликів. Система навчання публічного службовця має бути безперервною, гнучкою, адаптивною до змін у внутрішньому та зовнішньому середовищі.

Аналіз останніх досліджень і публікацій. Питання становлення системи освіти публічного службовця досліджували в своїх працях такі вчені, як: Ф. Тейлор [1], Т. Клікауер [2], А. Уэйкфилд [3], В. Бойко [8], С. В. Крисюк [10], Т. Лукіна, Н. Протасова, Л. Прокопенко та багато інших.

Мета. Узагальнення науково-прикладного доробку 3 досліджуваної проблематики, визначення основних класичних та інноваційних підходів в системі безперервного професійного навчання публічного службовця як базису для подальшого удосконалення публічного управління на всіх рівнях влади.

Виклад основного матеріалу. Еволюція підходів до навчання публічного службовця тісно пов'язана із трансформацією суспільства в контексті зміни 
моделей публічного управління та типу соціально-економічних систем. Вперше, у XVII-XVIII ст., зміст роботи публічного сектору спробували пояснити у своїх працях німецькі дослідники фон Зекендорф та фон Юсті, які розглядали монархію як інструмент служіння інтересам держави та їі громадянам в цілому. На основі досліджень того періоду набула розвитку наука про управління державним майном «камералістика» («камералізм»), акцент в якій був зроблений на централізованому стилі керування державою та досягнення високого рівня державного фінансового самозабезпечення [1], [2]. В результаті зростаючої потреби в спеціалістах з управління державним майном у XVIII ст. в Німеччині були створені камеральні факультети (нім. Kameralwissenschaft, Cameralia), провідною метою яких було надання освітніх послуг та формування нових знань та навичок у майбутніх службовців у сфері збільшення державного доходу. Слід зазначити, що камералізм як наука тісно пов'язаний з розвитком бюрократії в ранній сучасний період, оскільки він був методом, спрямованим на впровадження та підвищення ефективності ієрархічної системи камералістів (тодішніх публічних службовців) [3]. Поступово камералізм еволюціонує у теорію класичного державного управління, в основу якої були покладені принципи бюрократії.

Теорії класичного державного управління були широко впровадженні у систему навчання публічних службовців таких провідних країн початку ХХ ст. як США, Великобританія, Австралія, Німеччина та ін. Основоположниками таких моделей публічного управління були М. Вебер, В. Вільсон, Ф. Гундау та інші. Ключові питання даних теорій державного управління полягали у засвоєнні знань та набутті практичних навичок адміністрування як необхідного базису для державних реформ та забезпечення державного апарату спеціально підготовленими фахівцями, які не повинні були бути політично активними.

Пізніше, у 50-х рр. ХХ ст. з’явилася концепція публічного управління, в основу якої лягли праці Ф. Тейлора, Д. Муні, Ф. Гілберта, Г. Емерсона. Дана концепція базувалася на необхідності створення такої системи державного управління, яка б забезпечувала максимально ефективне досягнення мети 3 найменшими витратами. Дослідники пропонували впроваджувати в систему навчання державних службовців певні спеціалізації, які $б$ стали основою делегування відповідальності та розвитку корпоративної культури державного сектору.

У 1980-х рр. відбулася тотальна криза систем державного управління, які базувалися на бюрократичних та централізованих принципах. Виникла потреба у розбудові нової, більш гнучкої моделі публічного управління, яка б відповідала умовам стрімкого економічного розвитку світу. Моделі централізованого управління почали частково замінюватися моделями місцевого самоврядування, 
які були демократичними та відповідали суспільним викликам того історичного періоду.

Зміна централізованих методів управління на більш гнучкі та демократичні в Україні розпочалася після проголошення іiі незалежності у 1991 році. Слід зазначити, що дані зміни відбувалися дуже повільними темпами 3 причини низької адаптивної здатності системи державного управління до нових ринкових, турбулентних та невизначених умов. Початком розбудови нової національної системи навчання державного службовця можна вважати видання Указу Президента України «Про систему підготовки, перепідготовки та підвищення кваліфікації державних службовців» в травні 1995 року. Даним указом передбачалося створення Української академії державного управління при Президентові України (УАДУ, згодом - НАДУ) та іiі філіалів. Одночасно планувалося створити галузеву систему навчання при міністерствах та інших центральних органах влади [4].

В 1996 році вийшла постанова КМУ «Про центри підвищення кваліфікації державних службовців i керівників державних підприємств, установ i організацій», якою було зобов’язано уряд Автономної Республіки Крим та обласні державні адміністрації «активізувати роботу, пов’язану з перетворенням центрів в освітні, науково-методичні установи загальнонаціональної системи». В цьому ж році важливою постановою КМУ у сенсі розбудови національної системи освіти публічного службовця стала постанова № 321 згідно якої посади директора, його заступника та двох начальників відділів центрів підвищення кваліфікації державних службовців було віднесено до посад державної служби. Згодом, постанова КМУ 1997 р. № 55 затвердила оплату праці для працівників даних центрів у відповідності до аналогічних посад державної служби самостійних структурних підрозділів обласних державних адміністрацій [5-8]. В той період невизначеності стратегічних напрямів розвитку системи підготовки державних службовців дані постанови відіграли значну роль. Пізніше, у 2000 році була затверджена урядова Комплексна програми підготовки державних службовців, на основі якої здійснювалася підготовка державних службовців для органів центральної влади та органів місцевого самоврядування до червня 2020p. [9]. Програма грунтувалася на положеннях Конституції України, Законах України «Про державну службу», «Про освіту», «Про наукову i науково-технічну діяльність» та інших нормативно-правових актах, які регулюють питання в системі освіти державних службовців. Дана програма втратила чинність в 2020 році на підставі Указу Президента № 214/2020 від 5 червня 2020 р.

Підготовка та підвищення кадрового потенціалу публічної служби в сучасних умовах здійснюється на основі постанови КМУ від 6 лютого 2019 р. № 106 «Про затвердження Положення про систему професійного навчання 
державних службовців, голів місцевих державних адміністрацій, їх перших заступників та заступників, посадових осіб місцевого самоврядування та депутатів місцевих рад» та наказу Національного агентство України з питань державної служби (НАДС) від 26 листопада 2019 р. № 211-19 «Про затвердження Порядку організації підвищення кваліфікації державних службовців, голів місцевих державних адміністрацій, їх перших заступників та заступників, посадових осіб місцевого самоврядування» [11], [12]. В Законі України «Про державну службу» (ст. 48, 49) зазначено, що характер навчання державного (публічного) службовця має бути безперервним, тобто питання організації підвищення професійного рівня таких службовців має здійснюватися постійно. В Законі також визначено нову галузь знань «Публічне управління та адміністрування», яка замінила попередню «Державне управління».

Професійне навчання державних службовців може здійснюватися за рахунок фінансування 3 державного бюджету, а також за рахунок інших коштів, які не заборонені законодавством України. Здобуття професійних знань та підвищення кваліфікації проводиться на базі навчальних закладів, установ, організацій незалежно від форм власності, які мають законне право надання таких освітніх послуг.

Оновлена система професійного навчання публічного службовця грунтується на принципах інноваційності, практичного застосування, відкритості, цілеспрямованості та географічної наближеності надання освітніх послуг до місця проживання публічного службовця, який $\epsilon$ споживачем освітніх послуг. Інституційна структура системи професійного навчання публічних службовців представлена на рисунку 1.

За підсумками професійного навчання публічних службовців нараховуються кредити ЄКТС, які підлягають обліку та зобов'язані вести служби управління персоналом. Публічні службовці мають підвищити свою професійну компетентність не менше одного кредиту СКТС на рік (1 СКТС становить 30 годин).

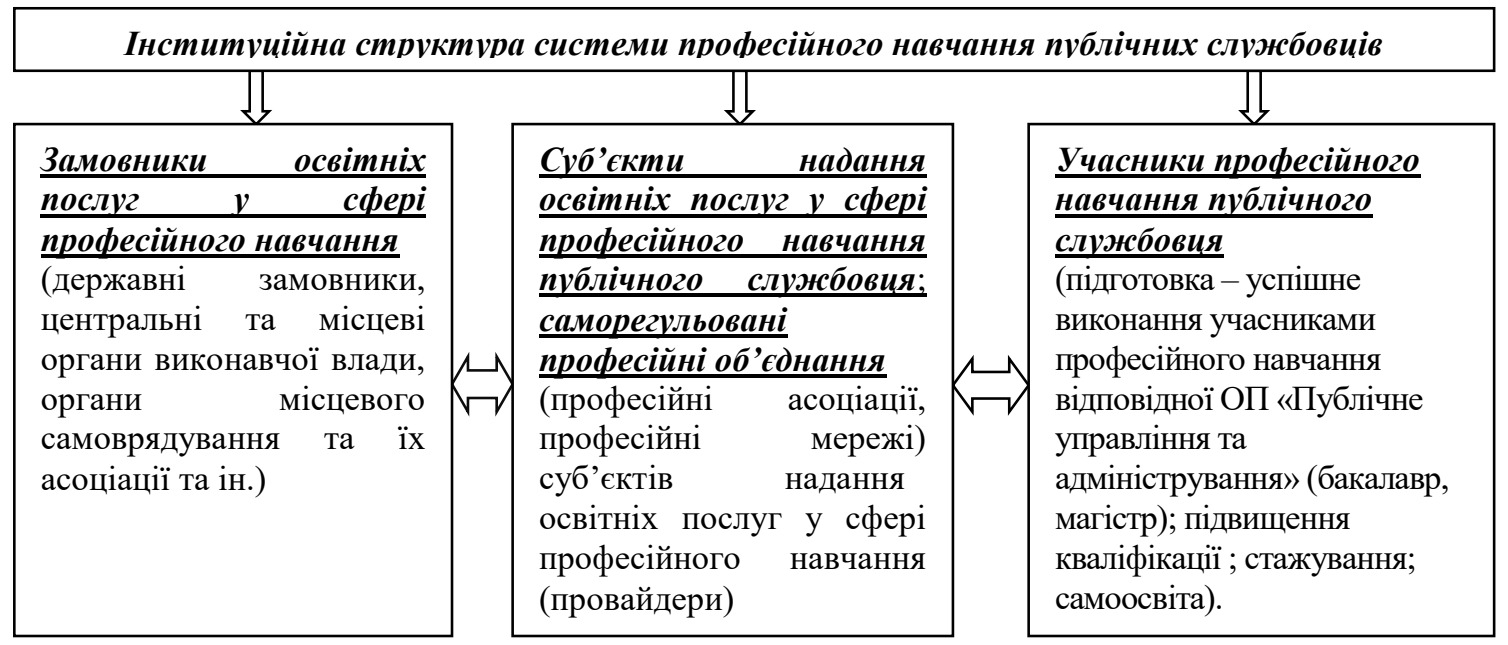

Рис. 1. Інституційна структура системи професійного навчання публічних службовиів

Джерело: сформовано авторами на основі [11-12]. 
Слід зазначити, що мережа навчальних закладів 3 професійної підготовки публічних службовців за спеціальністю «Публічне управління та адміністрування» та підвищення кваліфікації державних службовців формується НАДС на конкурсній основі з дотриманням певних вимог КМУ до учасників конкурсу (професорсько-викладацький склад, норми часу навантаження) та розміру передбаченого бюджету.

До національної мережі закладів системи професійного навчання публічних службовців входить:

- Національна академія державного управління при Президентові України (НАДУ) та їі 4 регіональні інститути;

- вищі навчальні заклади, які ліцензовані та акредитовані Національним агентством із забезпечення якості вищої освіти для підготовки бакалаврів та магістрів за спеціальністю «Публічне управління та адміністрування».

3 метою постійного підвищення якості надання освітніх послуг та результатів навчання вищими навчальними закладами мають проводитися опитування студентів, здобувачів, випускників, роботодавців, викладацького складу. В опитуваннях основний акцент робиться на задоволеність здобувачем процесом та результатами навчання, актуальність освітніх програм, відкритість та чесність оцінювання знань, доступність до навчально-методичного забезпечення та інше. Проведене анкетування серед здобувачів та роботодавців на базі Поліського національного університету (ЖНАЕУ) у 2018 р. свідчить про те, що здобувачі вищої освіти за спеціальністю галузі знань «Публічне управління та адміністрування» у цілому задоволені якістю навчання за обраною освітньою програмою (рис. 2). Серед відповідей респондентів 82 \% зазначили, що така задоволеність проявляється часто, 76\% учасників опитування вважають, що освітня програма $є$ актуальною. 


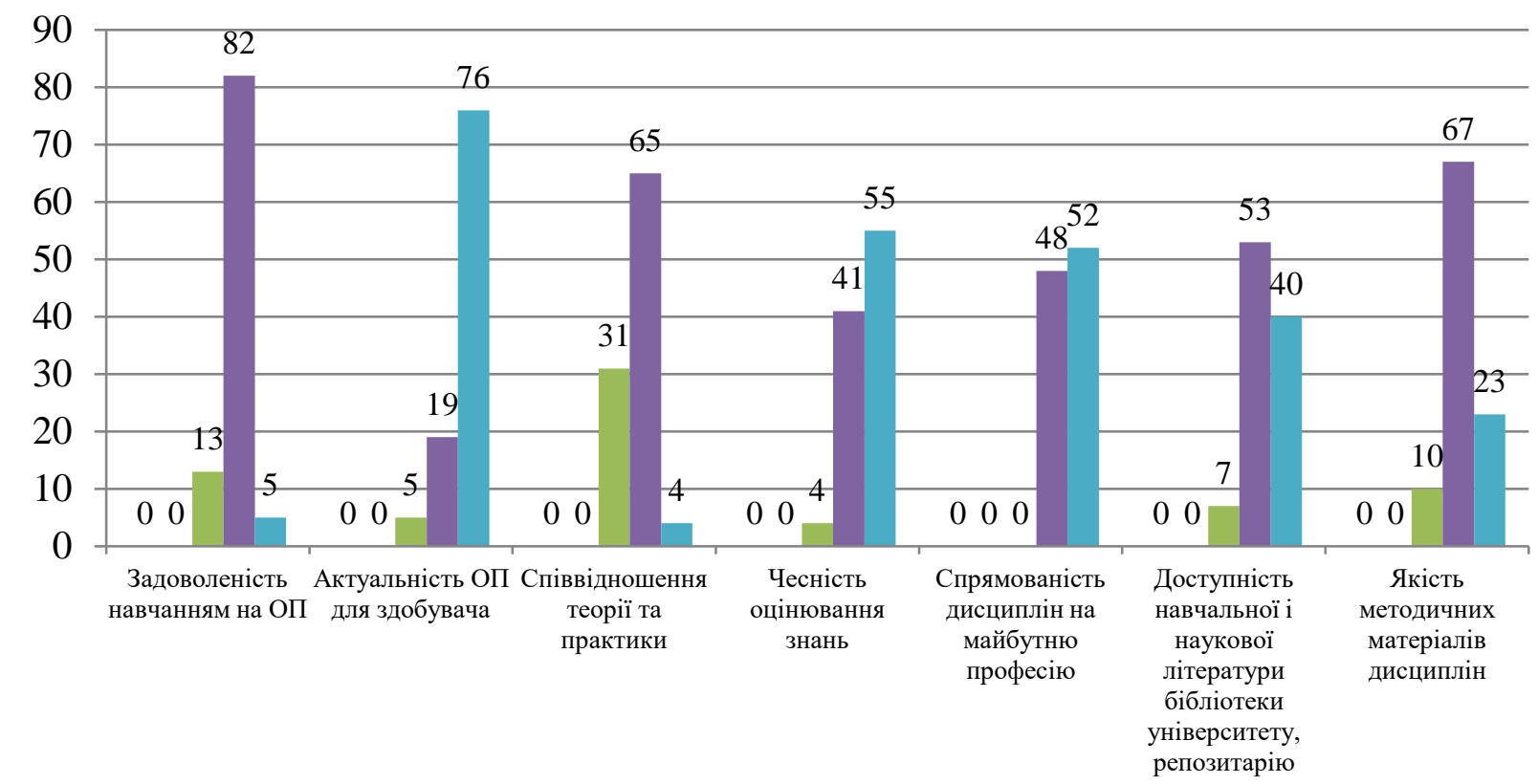

- 1 бал - якість відсутня;

- 2 бали - якість проявляється зрідка;

— 3 бали - якість проявляється на достатньому рівні;

п 4 бали - проявляється часто;

- 5 балів - якість проявляється практично завжди.

Рис. 2. Результати анкетування здобувачів вищої освіти за спеціальністю галузі знань «Публічне управління та адміністрування» Поліського національного університету (ЖНАЕУ), 2018 p.

Джерело: авторські дослідження.

Студенти також визначили достатній рівень співвідношення теорії та практики (65 \%). Крім цього здобувачі добре та відмінно оцінили спрямованість освітніх програм на майбутню професію.

Результати анкетування здобувачів щодо якості викладання дисциплін наведені на рисунку 3. Студенти відзначили високий методичний рівень занять (78 \%) та теоретичний рівень занять (70 \%). Було проведено також опитування серед роботодавців, результати якого представлені на рисунку 4. 


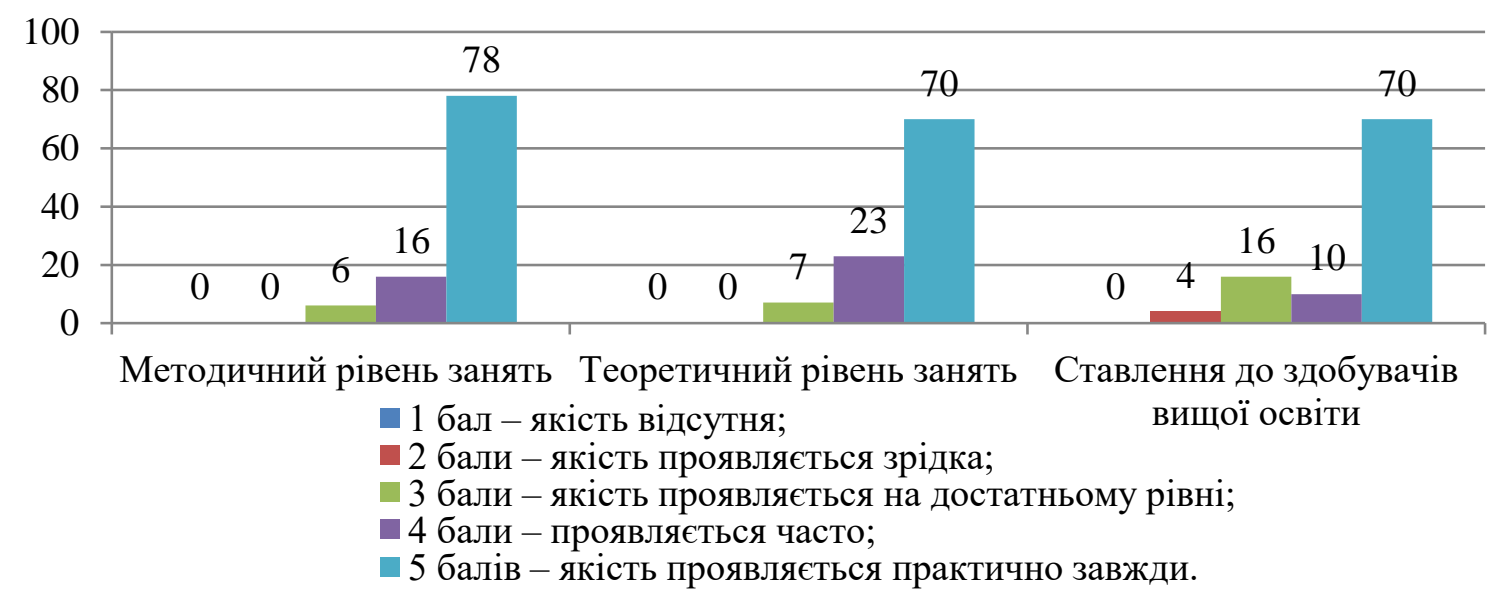

Рис. 3. Результати анкетування здобувачів спеціальності галузі знань «Публічне управління та адміністрування» Поліського національного університету (ЖНАЕУ) щзодо якості викладання дисциплін, 2018 р.

Джерело: авторські дослідження

Одним із ключових питань роботодавцям, було питання «наскільки Ви зацікавлені в прийомі на роботу випускників даного ВНЗ (Поліського національного університету)?».



Рис. 4. Результати анкетування роботодавців у сфері готовності прийняття на роботу на задоволення якості підготовки випускників Поліського національного університету (ЖНАЕУ), 2018 p.

Джерело: авторська розробка.

Більшість роботодавців відповіли на дане питання «повністю зацікавлений» (79\%), задоволені рівнем професійної підготовки випускників 90 \% від загальної кількості респондентів. 
Слід зазначити, що в результаті постійної комунікації з усіма зацікавленими сторонами професійного навчання публічного службовця, відбувається перегляд поточної ситуації стосовно актуальності освітніх програм, розробляються та впроваджуються інноваційні підходи щодо викладання та засвоєння дисциплін в офлайн та онлайн просторі, які забезпечують студентам нові знання та практичні навички в сфері публічного управління. Даний факт є особливо важливим в сучасних умовах стрімкого розвитку електронного врядування та вимушеного оцифровування значної частини навчального та управлінського процесу у зв’язку із появою та поширенням короновірусної інфекції COVID-19.

Висновки. В результаті аналізу літературних джерел та нормативноправового забезпечення розкрито сутність класичних та інноваційних підходів в системі безперервного професійного навчання публічного службовця. Так, в класичних підходах до навчання державних кадрів приділяється значна увага формуванню нових знань та навичок у сфері збільшення державного доходу, функціонуванні суспільних систем на основі централізованої ієрархічної моделі державного управління без проявів політичної активності службовців. Інноваційні підходи на відміну від класичних роблять значний акцент на здобуття нових знань та навичок в сфері державного управління на засадах демократії, децентралізації та відкритості влади, електронному урядуванні.

Аналіз історичних та соціально-політичних аспектів становлення сучасної національної системи професійного навчання публічного службовця дав змогу визначити основні принципи оновленої системи професійного навчання публічного службовця в Україні, серед яких провідними $є$ інноваційність, можливість прикладного застосування, відкритість, цілеспрямованість та географічна наближеність надання освітніх послуг до місця проживання публічного службовця.

Результати дослідження якості та результатів навчання студентів за спеціальністю «Публічне управління та адміністрування» на базі Поліського національного університету (ЖНАЕУ) свідчать про те, що в цілому студенти, здобувачі, випускники, роботодавці та викладацький склад задоволені процесом та результатами навчання. Перспективними напрямами удосконалення системи професійного навчання публічного службовця в контексті відповідності сучасним соціально-політичним та економічним викликам є посилення уваги на засвоєння публічними службовцями нових знань навичок в сфері електронного урядування, комунікаційних технологій влади та суспільства та протидії корупції.

\section{Лimepamypa:}

1. Тейлор Ф. Принципы научного менеджмента. Пер. с англ. А. И. Зак. - М.: Контроллинг, 1991. - 104 c. 
2. Klikauer, T. (2015). "What is Managerialism?” Critical Sociology 41 (7 - 8): $1103-1119$.

3. Wakefield, A. (2005), "Books, Bureaus, and the Historiography of Cameralism". European Journal of Law and Economics. Vol.19 (3), pp. 310-312, 318-319

4. Про систему підготовки, перепідготовки та підвищення кваліфікації державних службовців: указ Президента України від 30 травня 1995 року № 398/95. URL: https://zakon.rada.gov.ua/laws/show/398/95\#Text

5. Про центри підвищення кваліфікації державних службовців і керівників державних підприємств, установ і організацій: Постанова КМУ від 19 лютого 1996 р. № 224. URL: https://zakon.rada.gov.ua/laws/show/224-96-\%D0\%BF\#Text

6. Про віднесення деяких посад до четвертої і п’ятої категорій посад державних службовців: розпорядження КМУ від 29 квітня 1996 p. № 321-p. URL: https://zakon.rada.gov.ua/laws/show/321-96-\%D1\%80\#Text

7. Про оплату праці працівників центрів перепідготовки та підвищення кваліфікації працівників органів державної влади, органів місцевого самоврядування державних підприємств, установ та організацій: постанова КМУ від 27 січня 1997 р. № 558. URL: https://zakon.rada.gov.ua/laws/show/55-97-\%D0\%BF\#Text

8. Бойко. В. (2020). Історія становлення та розвитку системи професійного навчання державних службовців в Україні URL: https://pdp.nacs.gov.ua/news/istoriia-stanovlennia-tarozvytku-systemy-profesiinoho-navchannia-derzhavnykh-sluzhbovtsiv-v-ukraini

9. Про Комплексну програму підготовки державних службовців: указ Президента України 9 листопада 2000 року № 1212/2000. URL: https://zakon.rada.gov.ua/laws/show/1212/2000\#Text

10. Крисюк С. В. Державне управління освітою: навч. посіб. для слухачів, асп., докторантів спец. «Державне управління освітою» /С. В. Крисюк. - К. : НАДУ, 2009. - 220 с.

11. Про затвердження Положення про систему професійного навчання державних службовців, голів місцевих державних адміністрацій, їх перших заступників та заступників, посадових осіб місцевого самоврядування та депутатів місцевих рад: постанова КМУ від 6 лютого 2019 р. № 106. URL: https://zakon.rada.gov.ua/laws/show/106-2019-\%D0\%BF\#Text

12. Про затвердження Порядку організації підвищення кваліфікації державних службовців, голів місцевих державних адміністрацій, їх перших заступників та заступників, посадових осіб місцевого самоврядування: наказ Національного агентство України з питань державної служби (НАДС) від 26 листопада 2019 p. № 211-19. URL: https://zakon.rada.gov.ua/laws/show/z0005-20\#Text

\section{References:}

1. Taylor, F.W. (1991). The Principles of Scientific Management [Printcipy nauchnogo menedzhmenta]. (A. I. Zak, Trans). Moscow: Kontrolling [in Russian].

2. Klikauer, T. (2015). What is Managerialism? Critical Sociology, 41(7-8), 1103-1119 [in English].

3. Wakefield, A. (2005). Books, Bureaus, and the Historiography of Cameralism. European Journal of Law and Economics, 19 (3), 311-320 [in English].

4. Ukaz Prezydenta Ukrainy "Pro systemu pidhotovky, perepidhotovky ta pidvyshchennia kvalifikatsii derzhavnykh sluzhbovtsiv" : vid 30 travnia 1995 roku, № 398/95 [Decree of the President of Ukraine "On the system of training, retraining and advanced training of civil servants" from May 30 1995, № 398/95]. zakon.rada.gov.ua. Retrieved from https://zakon.rada.gov.ua/laws/show/398/ 95\#Text [in Ukrainian]. 
5. Postanova KMU "Pro tsentry pidvyshchennia kvalifikatsii derzhavnykh sluzhbovtsiv i kerivnykiv derzhavnykh pidpryiemstv, ustanov i orhanizatsii” : vid 19 liutoho 1996 r., № 224 [Resolution of the Cabinet of Ministers "On advanced training centers for civil servants and heads of state enterprises, institutions and organizations” from February 19 1996, № 224]. zakon.rada.gov.ua. Retrieved from https://zakon.rada.gov.ua/laws/show/224-96-\%D0\%BF\#Text [in Ukrainian].

6. Rozporiadzhennia KMU "Pro vidnesennia deiakykh posad do chetvertoi i piatoi katehorii posad derzhavnykh sluzhbovtsiv” : vid 29 kvitnia 1996 r., № 321-r [Order of the Cabinet of Ministers "On the assignment of certain positions to the fourth and fifth categories of positions of civil servants" from April 29 1996, № 321-r]. zakon.rada.gov.ua. Retrieved from https://zakon.rada.gov.ua/laws/show/321-96-\%D1\%80\#Text [in Ukrainian].

7. Postanova KMU "Pro oplatu pratsi pratsivnykiv tsentriv perepidhotovky ta pidvyshchennia kvalifikatsii pratsivnykiv orhaniv derzhavnoi vlady, orhaniv mistsevoho samovriaduvannia derzhavnykh pidpryiemstv, ustanov ta orhanizatsii” : vid 27 sichnia 1997 r., № 558 [Resolution of the Cabinet of Ministers "On remuneration of employees of centers for retraining and advanced training of employees of public authorities, local governments of state enterprises, institutions and organizations" from January 27 1997, № 558]. zakon.rada.gov.ua. Retrieved from https://zakon.rada.gov.ua/laws/show/55-97-\%D0\%BF\#Text [in Ukrainian].

8. Boiko, V. (2020). Istoriia stanovlennia ta rozvytku systemy profesiinoho navchannia derzhavnykh sluzhbovtsiv $\mathrm{v}$ Ukraini [History of formation and development of the system of professional training of civil servants in Ukraine]. zakon.rada.gov.ua. Retrieved from https://pdp.nacs.gov.ua/news/istoriia-stanovlennia-ta-rozvytku-systemy-profesiinoho-navchanniaderzhavnykh-sluzhbovtsiv-v-ukraini [in Ukrainian].

9. Ukaz Prezydenta Ukrainy "Pro Kompleksnu prohramu pidhotovky derzhavnykh sluzhbovtsiv" : vid 9 lystopada 2000 roku, № 1212/2000 [Decree of the President of Ukraine "On the Comprehensive Training Program for Civil Servants” from November 9 2000, № 1212/2000]. zakon.rada.gov.ua. Retrieved from https://zakon.rada.gov.ua/laws/show/1212/2000\#Text [in Ukrainian].

10. Krysiuk, S. V. (2009). Derzhavne upravlinnia [State management of education]. Kyiv: NADU [in Ukrainian].

11. Postanova KMU "Pro zatverdzhennia Polozhennia pro systemu profesiinoho navchannia derzhavnykh sluzhbovtsiv, holiv mistsevykh derzhavnykh administratsii, yikh pershykh zastupnykiv ta zastupnykiv, posadovykh osib mistsevoho samovriaduvannia ta deputativ mistsevykh rad" : vid 6 liutoho 2019 r., № 106 [Resolution of the Cabinet of Ministers "On approval of the Regulations on the system of professional training of civil servants, heads of local state administrations, their first deputies and deputies, local government officials and deputies of local councils” from February 6 2019, № 106]. zakon.rada.gov.ua. Retrieved from https://zakon.rada.gov.ua/laws/show/106-2019$\%$ D0\%BF\#Text [in Ukrainian].

12. Nakaz Natsionalnoho ahentstvo Ukrainy z pytan derzhavnoi sluzhby (NADS) "Pro zatverdzhennia Poriadku orhanizatsii pidvyshchennia kvalifikatsii derzhavnykh sluzhbovtsiv, holiv mistsevykh derzhavnykh administratsii, yikh pershykh zastupnykiv ta zastupnykiv, posadovykh osib mistsevoho samovriaduvannia" : vid 26 lystopada 2019 r., № 211-19 [Order of the National Agency of Ukraine for Civil Service (NAPS) "On approval of the Procedure for organizing professional development of civil servants, heads of local state administrations, their first deputies and deputies, local government officials” from November 26 2019, № 211-19]. zakon.rada.gov.ua. Retrieved from https://zakon.rada.gov.ua/laws/show/z0005-20\#Text [in Ukrainian]. 